\title{
Teacher Trade Unionism as a Political Ideological State Apparatus within the South African Education System: A Structural Marxist Perspective
}

\author{
Prof Thulani Zengele \\ University of South Africa, College of education, \\ Department of Educational Leadership and Management \\ tzengele@unisa.ac.za
}

\section{Doi:10.5901/mjss.2014.v5n9p470}

\section{Abstract}

This article presents a discussion of the politics of teacher trade unionism as an Ideological State Apparatus operating within a Repressive State Apparatus using the structural Marxist perspective. Using Althusser's work, I critique the politics and processes of the redeployment process within the South African education system. Redeployment is a process that was introduced in South Africa to prevent the retrenchment of teachers in under populated schools when learners moved from lowperforming to high-performing schools after the birth of one new democratic education system in 1994. I argue that the South African Democratic Teachers' Union (SADTU) fits the profile of a political Ideological State Apparatus and has been immensely influential in fortifying the emergence of the current ruling class hegemony within the Department of Education. While the function and structure of ideology are unchanging and existing throughout history, my postulation is that SADTU still strives to make a significant impact to the ideological role of the State as it 'normalises' an immensely hierarchical society. Nevertheless the fact Althusser's theories were born out of an effort to preserve what some viewed as Communist convention; I find Althusser's work critical and relevant in critiquing the redeployment and rightsizing process within the South African education system.

Keywords: Ideological State Apparatus, Repressive State Apparatus, SADTU, Redeployment, Teacher Unions.

\section{Introduction and Background}

The proliferation and growing intensity of teacher unionism in South Africa as a developing state poses certain challenges because of the manifestation of the application of the power of both the state as a Repressive State Apparatus (RSA) together with the unions as Ideological State Apparatuses (ISA). Louis Althusser (1971:143-4), a French philosopher and a structural Marxist, posits that the replication of labour power requires not only a replication of its skills, but also a reproduction of submission to the ruling ideology for the workers. In addition he argues it requires a reproduction of the ability to manipulate the ruling ideology correctly for the agents of exploitation and repression. The protracted intention is that the ISAs too, will provide for the domination of the ruling class. The actions of the ISA when acting on the mandate of the RSA become ubiquitous during the implementation of redeployment policies within the perimeters of the Department of Education structures.

Against the background of this cited context I further argue that transactional leadership as a leadership style is used by the South African national leadership as well as by high-ranking members of the South African Democratic Teachers' Union (SADTU) to enforce allegiance by ordinary members in either mysterious or at times describable manners as already described in the preceding paragraph. I further argue that this could lead to repression and corruption while preserving hegemony over the ordinary union members who are mainly teachers occupying the lower echelons of the hierarchy. As Althusser (1971:112) writes, "ideology has material existence because an ideology always exists in an apparatus and its practices." Althusser (ibid) further argues that "ideology always expresses itself through actions, which are converted into practices, for example, rituals, conventional behaviour, and leadership." In the context of this article, rituals can be seen as acts of nepotism and placing comrades that are declared in excess, in attrition for senior positions.

This article departs from the assumption that SADTU has all the necessary characteristics of an ISA by the mere observation of the way rank and file union members are treated when redeployment has to take place. This article also aims at discussing the effects of repressive practice on the morale of teachers in South Africa from the findings of a study conducted by Zengele in 2009. I agree with Althusser's structural Marxist views that teacher unions are ISAs in a disguised fashion as they never publicly acknowledge that this is their real identity. They do this for example by using the 
word 'comrade' in a seemingly patronising manner when addressing the followership of the union during mass meetings and one-on-one interaction. Althusser (1971:112) argues that trade unions "manipulate their members by the means of exclusion and selection when they are perceived as non-conforming". He further posits (1971:112) that "unions are one of the means by which workers are indoctrinated into modes of thought favourable to the continuation of capitalism". I recognise SADTU's immense contribution towards the realisation of a democratic society and equal educational opportunities for all South Africans. However, the same SADTU is viewed as propagating "the reproduction of the relations of production by reference to aspects of ideological and political practice" (Zengele \& Pitsoe 2014).

The article consists of four parts. In the first part, I conceptualise ideology and ISAs. In the second part, a critical analysis of the redeployment process through Althusser's lens is discussed. Thirdly, an examination of the transactional leadership style of SADTU leadership as an ISA is conducted. In the last part, I explore the perceptions of SADTU teacher members of the redeployment process following the research conducted by Zengele (2009), Diko and Letseka (2009), Pattillo (2012) and Letseka, Bantwini and King-McKenzie (2012).

\section{Conceptualising Ideology and Ideological State Apparatuses}

Althusser (1971:143-4), also known as a theorist of ideology, distinguishes between what he calls Repressive State Apparatuses (RSAs) which can be government, administration, army, police, courts or prisons, and Ideological State Apparatuses (ISAs) which could be regarded as religion, education, family, law, politics, trade unions, communication and culture. In Althusser's view, the ISA is an instrument or mechanism that is used by the state to promote capitalist values. Althusser (1971) hypothesizes that apparatuses always consist of ideologies and that while ideology in general has no history; specific ideologies have a history of their own. As Althusser (1971) discerns, ideology cannot be detached from the society it is situated in as it originates from the day-to-day activities of individuals that make up these societies. As such, ideology forms the basis of our existence and is responsible for the individual's perception about the way we regard our experiences.

Althusser (1971) conjectures that though the ISAs appear to be quite contrasting and dissimilar, they are incorporated by subscribing to a common ideology that is controlled by the ruling class which in the case of South Africa is the African National Congress (ANC). SADTU is affiliated to South Africa's major labour union, the Congress of South African Trade Unions (COSATU), which is part of the tripartite alliance with the ruling party and the South African Communist Party (SACP). Incontrovertibly, the State has to ensure a certain amount of hegemony over the unions in order to ensure that it remains in power. The ruling party does this by excluding or intimidating those that do not show support for its endeavour to remain in control. To exercise this control and domination, the ruling party has to ensure that those who appear to be supportive are rewarded and those who work against the mandate of the ISAs face restrictions, as will be explained further in this article.

Althusser bowed to the demesne of ideology by following Antonio Gramsci, a political theorist and philosopher. While Althusser compares 'ideology' to Freud's 'unconscious', Althusser's writing presents ideology in a way that is similar to the French philosopher Derrida's presentation of the language of major importance. His thesis states that ideology converts those that are followers by a process of interpellation or behaving obsequiously to the leadership with the expectations for favours. In this case, favours could be ascribed to the preferential treatment when those considered as being close to the union leadership, better known as 'comrades' are redeployed to positions of power within the department of education. Althusser (1971) hypothesizes that all the subjects, from the moment of their birth, are already participants in the material practices of ideology. He further believes that the overriding beliefs, values and practices that constitute ideology serve a political duty to prolong the hegemony of the working class who, for the purpose of this article, are the teachers. Teachers regard themselves as workers and not professionals due to the low salaries and working conditions to which they are subjected, as argued by Zengele (2009).

Althusser (1971144) speculates that "in order to exist, a social formation is required to essentially, continuously and perpetually reproduce the productive forces, the conditions of production and the relations of production". The RSA ensures that the oppressed are paid paltry salaries so that they remain indebted to the State and are kept at lower levels of the hierarchy within the education system with promises by union leaders to fight for teachers' rights, improved working conditions and improved salaries. Zengele and Pitsoe (2014) state that "the reproduction of the conditions of production and the reproduction of the relations of production happen through the Ideological State Apparatuses which are treacherous machinations controlled by the capitalist ruling ideology in the context of a class struggle to repress, exploit, extort and subjugate the ruled class". Althusser contends that for any ruling class to remain in power over a long period there must be domination over and in the ISA simultaneously. The association of SADTU with government in South Africa and the appointments of SADTU senior leaders by means of redeployment to very senior government positions without 
the relevant qualifications is better known as 'redeployment' in South African terms. Althusser's contention is a more challenging proposition. He notes that "the reproduction of the relations of production is secured by the legal-political and ideological superstructure" (1971:113-4). For him, it is secured by the exercise of state power in the RSA and the ISAs. Furthermore, the role of the RSA consists fundamentally in fortifying by power the political circumstances of the duplication of relations of production which are in the last option associations of corruption and anarchy. The RSA also safeguards its position by inhibiting the political conditions for the actions of the ISAs. The use of rewards for supportive behaviour and punishment for resistant behaviour is a case in point in this discussion.

SADTU therefore fits the profile of a political ISA by virtue of the arguments already made above. It is worth mentioning that Althusser's ideological state apparatuses work through material practices which interpolate into subjects of ideology. Within this context, SADTU as an ISA has been immensely efficacious in fortifying ruling class domination within the Department of Basic Education (DBE) in South Africa. SADTU, in my view contributes massively towards the ideological role of the State, in that it 'normalises' an enormously hierarchical society in South Africa. The research by Letseka et al. (2012) and Pattillo (2012) confirms that in terms of union leadership structures, for teachers to become selfactualised and self-fulfilled they must carry out the mandate of the union and not of the Department of Basic Education.

\section{A Critical Analysis of Redeployment through Althusser's Lens}

It is first necessary to point out the inadvertent association between the redeployment process and Althusser's work. In doing so, I ground my philosophical account with a brief illustration, that the implementation of teacher redeployment policies has an interdependent relationship. To start with, Althusser's work, Ideology and Ideological State Apparatuses (1971), is not unacquainted in critiquing the ideology that is infused in politics. Althusser's work could validate the functioning and understanding of the education department's practices when it comes to the redeployment of teachers and other senior union officials to new posts.

From my point of view, there is an assumption that transformational leadership principles should inform and guide processes of redeployment in South Africa. From the critical theoretical paradigm it becomes apparent that the expected implementation of the redeployment policies is not congruent with the actual implementation process. Rather, SADTU, as argued in the previous section, through transactional leadership, perpetuates the reproduction of the relations of production by reference to aspects of ideological and political practice. In essence, transactional leadership advocates that all subjects must fall in line with the doctrines of the ruling class as embedded in structural Marxist views.

It is worth commenting on the matter of hegemony as both a social and a multi-layer construct. I do not wish to fully explain the pendantics of hegemony, given that a useful abundance of literature on the subject already exists. I argue though, that it is critical to have a common understanding of what hegemony entails. Implicitly, hegemony is the dominance of the society's classes in maintaining the socio-political status quo (Pitsoe, 2012). Akita (2010) aptly notes that hegemony, as a theory, has been used in virtually all spheres of human endeavour and in all kinds of relationships that suggest inequality.

In practice, the activities informing and guiding the redeployment process are characterised by an autocratic approach and they perpetuate the capitalist hegemony. Pitsoe and Letseka (2013:24) contend that "in hegemony, the oppressed class literally grants the oppressors permission to oppress them". They further argue that most of the hegemony occurs through social practices and beliefs which neither the oppressors nor the oppressed are aware of, thus the necessity for raising the cognisance of people as a precondition for real freedom. Pitsoe \& Letseka, (2013:24) argue that in most situations, both the oppressors and the oppressed are fully cognisant of their activity since the reward or punishment is evident after every act of support or resistant behaviour.

Against this background, Althusser's thoughts offer neither a truly structuralist nor a poststructuralist account of the effects of the ideology that is infused in politics and the redeployment process. Section 8(2) of the Employment of Educators' Act 84 of 1998 (EEA) states that redeployment may only be completed with the approval of the School Governing body (SGB) and subsequently endorsed by the Director-General of the Department of Education (DoE). The purpose is to ensure that teachers can work in an atmosphere that is free of nepotism and discrimination when teachers are redeployed. The research results aim at revealing if this does indeed happen as stated in policy.

The embryonic nature of the teaching profession in the newly formed democratic education system in South Africa requires high-performing, relevantly qualified and dedicated teachers in order to meet educational goals under the leadership of operational educational managers. While I acknowledge that the South African education system demands quality and new skills from educational leaders, the process of identifying and redeploying excess teachers in South African schools has been problematic as it is linked to the filling of promotional posts. Zengele (2009) argues that there is a salient notion that teachers who perform poorly in the classroom and are regularly absent from school due to union 
activities are easily declared in excess and redeployed. Van Onsellen (2012) and Pattillo (2012) refer to the practice of placing "comrades" in management positions as "cadre deployment". Pattillo (2012) describes cadre deployment as an unwritten policy of patronage-based political appointments to school leadership positions. In a study by Diko and Letseka (2009) on teacher attrition, it was found that there is an abundance of management-aspiring teachers with honours, master's and even doctoral degrees in educational leadership who are side-lined during the selection and redeployment process in favour of excess and highly unionised teachers.

Resolution 6 of 1998 and Section 3.6 of the EEA state that all teachers should be fairly treated during the redeployment process. The fact that excess teachers, according to Resolution 6 , have to be given priority when promotional posts are filled leaves the DoE with no choice but to consider such teachers for promotion. Sayed (2002:29) refers to this as the "policy gap", that is understood as the "mismatch between policy intention, practice and outcome" since those identified as in excess and undesirable within the teaching profession by some principals of schools end up being promoted into management positions and in turn become managers if the vacant post was a more senior one.

In view of the critical role played by SADTU in the post-apartheid education transformation, its influence in teacher redeployment cannot be underestimated. Notably, the core values of democracy are not entrenched in the redeployment to current promotional posts and those that are declared in excess. With the devolution of management to the individual school site, I argue that the implementation of teacher redeployment policies is perforated by corrupt practice and favouritism as argued by Letseka et al. (2012) and Pattillo (2012). Both processes lack the democratic values and an ingredient of excellence.

\section{Transactional Leadership as Ideological State Apparatus}

Taking the reader along the journey involving the implementation of teacher redeployment policy practice in the South African context, it becomes clear that transactional leadership is an instrument of power that is conveniently used by the state to maintain its power. There is a social system to effect its power, and use it as a tool of political hegemony. With this in mind, this section focuses on the notion of the transactional leadership style of management as espoused by the South African DBE. Burns (1978) hypothesises that transactional leadership involves an exchange of rewards for positive and supportive behaviour. Bass (1985) also claims that there are two forms of transactional leadership behaviour: the contingent reward behaviour and the contingent punishment by others theories, as cited in Mackenzie, Podsakoff and Rich (2001:117-118). The contingent reward behaviour theory becomes apparent when followers adhere to the mandate of the ruling class which is to assist in keeping them in power. In the SADTU context, the reward for loyalty to the union is the redeployment to higher positions without the need for relevant qualifications to occupy that particular post. According to Diko and Letseka (2009), this translates to power, recognition and higher salaries. These authors argue that teachers are often motivated to apply for management positions by the high salary packages rather than by the desire to lead schools effectively.

As mentioned earlier, the research by Letseka et al. (2012) and Pattillo (2012) confirms that in union language doing well in education means carrying out the mandate of the union and not of the DBE. The ministerial review on school governance in 2004 resonates to the fact that there is a drive to transform school management by means of both decentralisation and transactional leadership practices. I argue that such a process tends to benefit certain groups. In the South African context, the dominant group that stands to benefit from decentralisation is SADTU which is a constituency of the tripartite alliance with the ruling party.

Besides, SADTU has been instrumental in keeping the current government in power by encouraging teachers to vote for the ANC in every election as teachers form a significant section of the informed population. The transactional form of leadership that has transcended through the ranks within the DBE tends to benefit SADTU while compromising on values of good school governance. The transactional leadership theoretical perspective as a unit of analysis is relevant in this article on the basis that the current trends in educational leadership seem to focus on loyalty to the union rather than to the needs of schools as will be argued during the discussion section of this article.

It is important at this stage to remind the reader that the transfer of educators from low performing to high performing schools is better known as the "redeployment" or "rationalisation" process. Resolution 6 of 1998 states that procedures should be in place for the rationalisation and redeployment of educators, and those educators should not be declared redundant, thus leading to their retrenchment. According to this resolution, the process was supposed to start on 5 February 1999 and end by 30 June 1999. The process is still on-going, although in a different manner. The following section reports on findings during focus group interviews as part of a study by Zengele (2009) described below. 


\section{General Perceptions of Teachers on the Role Played by Unions during the Redeployment Process}

Findings under this section emanate from Zengele's (2009) research that was conducted in the Gauteng province of South Africa. The thesis, entitled "The involvement of teacher unions in the implementation of the Employment of Educators' Act 78 of 1998", reports on the teachers' perceptions of the expected union participation during the redeployment process and their perceptions on the actual involvement of unions during the redeployment process. It provides teachers' recommendations on corrective action and suggestions for further research.

The participants' responses are presented in the following section and their actual comments are typed in italics.

\subsection{Report on the results}

\subsubsection{Responses by teachers on the expected role of the unions}

All the teachers who were interviewed agreed that redeployment at school level was a sensitive issue which had been manipulated by some principals, SADTU and district officials. They agreed that they expected their unions to protect them rather than acting in their own interests.

One teacher commented: ... so that the robbing and cheating system is eliminated. Teachers insisted that unions were expected to observe the identification process closely because they were supposed to protect their members. One teacher added, I think the ultimate role of the unions is to see to it that schools are supplied with suitable personnel to run schools, not what they are doing right now. The teachers knew that the role of teacher unions during the redeployment process was to serve as observers. This expectation is in line with the contents of Collective Agreement 2 of 2005. Another teacher noted that the expected role of unions was to represent teachers at school level to ensure that proper steps are taken according to the Schools Act.

The teachers thoroughly understood the exact conditions under which redeployment had to take place. They explained that when a school needed an additional teacher, the principal was required to discuss the matter with the School Management Team and the teachers while the union representative remained an observer. The criteria for the filling of vacant posts were reported to be the curricular needs of the school, also taking equity into consideration. Another teacher stressed that there should be fairness and transparency. In the process they explained the process of seeking final approval through the hierarchy structures of the DoE. She added, observing that procedurally and substantively procedures are followed. All groups agreed that the principal and the SGB played a major role. Teachers reported that they expected the unions to act in our interests in this regard for our improved morale. However, the teachers indicated that the Last In First Out (LIFO) was not a good procedure as the most valuable teacher in the school usually had to leave as a result of the LIFO especially when the teacher was not in good terms with the principal who had been a former union official. The teachers' understanding was found to be in line with Section 3.2.1(d) of Collective Agreement no. 2 of 2005 which was agreed to by all stakeholders in the Education and Labour Relations Council (ELRC).

\subsubsection{Responses of teachers on the actual role of the unions}

Teachers reported that unions were only interested in the redeployment process when the move meant getting transferred to a promotional post. One teacher said, they only care about money, so they will do anything to ensure that their comrade gets the promotion. Another teacher commented, from post level 2 which is for the head of department to post level 4 which is the principalship, tempers flared because it was a matter of an improved salary package now and not about commitment. Another teacher added, if it is a post level 1 post you hardly see them, come promotional posts they start being aggressive and intimidating.

The same teachers further explained that during the previous year the principal had consulted the staff and had afterwards been told by the district official that it was wrong to do so. Teachers were therefore of the opinion that the principal and the district official were conspiring against them because both the principal and the district official were former SADTU officials promoted through corruption. The teachers expressed their concern that they too needed the protection of the unions. One teacher said, if you are a teacher and you are told by the principal that the district official has identified you to be in excess, you cannot trust that. It's worse if you know that it was not the district official that identified you but the principal himself together with the union friends. Another teacher stated that redeployment significantly dampened their spirits.

The teachers expressed a loss of faith in the redeployment process because each time a teacher was to be identified it was always the one who was either not in good terms with the principal or a key union member, if the 
redeployment meant moving to a senior position. One teacher asked, what is the use of doing the honours and master's degrees if promotions are acquired so easily? In some instances it was the teacher who was regularly absent from school due to union work that would be declared in excess. They also mentioned that at times it would be the one that always questioned the leadership style of the principal at school level that would be punished with redeployment. Teachers were of the opinion that the education system was regressing to the state of affairs that prevailed in the apartheid era which was characterised by harassment because of the actions of certain principals and government officials at the time.

Some teachers reported that the curricular needs of the school were not considered when deciding on which teacher should be declared in excess. One teacher said, if the principal doesn't like you, you just go. All teachers who were interviewed concluded that they were willing to leave the teaching profession because of corruption. One teacher said, as you see sir, we are not doing our preparation right now but reading newspapers to find posts elsewhere. When I asked why the teachers did not report activities that demotivated them, one of them answered, How can you report nepotism if the director or district manager was also deployed by SADTU? From the responses by the teachers in all the interviews it became clear that they were utterly demotivated.

\subsubsection{Teachers' responses on suggested corrective action}

All teachers agreed that the authorities should ensure that the curricular needs of the school should always be carefully taken into account before a teacher was to be considered to be in excess. The teachers also said that the participation of unions during the redeployment process should be closely observed by the Department of Basic Education officials. One teacher added, you see sir; it's good that they remain as observers because they take over the process if the other union does not attend. They were strongly of the opinion that decisions on who should be declared in excess and redeployed should be taken by teachers themselves together with the union and the principal, using work allocation records. The teachers said that decisions taken in this way would not leave a bitter pill in the teacher's mouth. Another teacher added, the solution is ... to get the DoE to pay educators for qualifications passed so that this nonsense of clamouring for promotion posts could end. It is really very depressing. She continued, Perhaps educators would be more interested in teaching, and the unions can rather represent us during disciplinary hearings." I took note during the interviews that most of the teachers' concerns emanated more from SADTU involvement in policy implementation than the other stakeholders' involvement. In the following section a discussion on the research findings is presented based on the comments and arguments by teachers during the interviews.

\subsection{Discussion}

It is apparent that Althusser's (1971) idea of the Repressive State Apparatus and the relationship with the Ideological State Apparatuses is used successfully to sustain hegemony of the ruling class in South Africa. It is abundantly clear that teachers still need the support and assistance of the union when it comes to redeployment as it is used as punishment for those who do not support SADTU by not attending their meetings during teaching hours. At the same time the same union that is expected to protect its members is reported to be looking only after the needs and interests of its key members when the redeployment process involves the movement to a promotional post. In my view it appears that this is done in order to preserve the hegemony of the ruling class. It is important to highlight that the school-based teachers do have the necessary qualifications to fill senior positions as part of redeployment but are sidelined. The affected teachers regard this approach as being repressive. Diko and Letseka (2009) point out in their research that this process is motivated by a desire for high salaries and good perks. The probing during interviews indicated that those who are in excess are usually those who are regularly absent from school due to union responsibilities during school hours. Allowing teachers to do union work during teaching hours can be interpreted as desperate means used by the state to extend their stay in office by allowing unions to do as they wish because they owe their success to them. In general, the teachers' views on the expected involvement of unions in the rationalisation process seem to be in line with the departmental policy as they are fully cognisant of their rights and obligations. The same can be viewed as a direct cause for the low teacher morale because of the reported role played by the unions.

While teachers view a discussion between the principal and the district official with suspicion, Circulars 43/2006 section 3.6 and 55/2008 as enshrined in the Employment of Educators' Act, allow these meetings to take place. The involvement of the unions during the redeployment process as an Ideological State Apparatus shows in the findings that it is not aimed at ensuring the smooth running of the process but at preserving the interests of the hegemony of the ruling class.

In this article the focus is on governance and management in education. Burchell (1993267-282) describes 
"governance" as an act for acting on the actions of others. In this case it is the unions wrenching the control of redeployment process from SGBs in order fulfil their objectives. Teachers do not view such an act as redeployment but as a form of harassment as espoused by Burns' $s$ (1978) punishment by others theory. Althusser's (1971) viewpoint is the same: he attributes redeployment to the transactional leadership used by the Repressive State Apparatus to maintain its hegemony over the oppressed teachers. The study by Pattillo (2012) on 'Quiet corruption' in the South African province of KwaZulu-Natal revealed that those who try to change the SADTU practice have received great resistance. Pattillo (2012) refers to the case of Ntombela, a district manager deployed by SADTU. Ntombela refused to support political appointments and was met with such resistance by SADTU that he had to resign from his post after his car tyres were slashed and his office vandalised. Letseka et al. (2012) refer to similar events in Greece where Marietta Giannakou, a former unionist official, lost her parliamentary seat because of insisting on teacher accountability. Letseka et al. (2012) also refer to the USA case of Michelle Rhee, who was deployed by a union, who closed ineffective schools and advocated for merit pay before the unions used their political muscle to force her to resign. This goes a long way in explaining the state's power as a Repressive State Apparatus when using its Ideological State Apparatus, the unions, to either reward or punish those who do not conform to what is expected and those who do.

Moe (2011:33) points out that even in the USA the bureaucracy of the Department of Education is overwhelmed by patronage-based public appointments. This shows that the problem of nepotism is therefore not unique to South Africa. It is also evident that teachers regard district officials, the principals and SADTU - which are Ideological State Apparatuses- as being responsible for nepotism in schools. The deployment of SADTU-aligned officials is seen as the reason for failure to report nepotism since these officials are more loyal to the union than to the DoE. Govender (2004:267) refers to the relationship between SADTU and the ANC prior to the first democratic elections in South Africa as the reason why the country is plagued with this seed of corruption and nepotism. The redeployment of SADTU key members (loyalists) undermines the impartial selection of suitably qualified teachers to management positions and this lowers teacher morale. Diko and Letseka (2009) concur that due to the "tailor-made requirements set when advertising promotional posts to suit the SADTU candidate, there is no reason why teachers should not leave the teaching profession". Taylor (2012) also reported that the promotion of teachers and other officials using the redeployment process has fuelled the widespread public perception that union activity is primarily about advancing the authority and benefit of the union members. The burning question also raised by teachers is how to abolish such acts of nepotism when those in management positions are also SADTU deployees.

This question becomes even more pertinent when Gwede Mantashe in City Press (2011), the Secretary-General of the ruling party, the ANC, defends cadre deployment as a way of correcting the imbalances of apartheid and not a sin. Mantashe (ibid) concedes, however, that the applicants must meet the basic requirements to fill a promotional position. I also argue that the basic requirements set, namely is a bachelor's degree or diploma in any discipline, is not sufficient to qualify for a management position within the DoE. I further contend alongside Diko and Letseka (2009) that there are many teachers with master's and doctoral degrees who are overlooked when teachers are redeployed to promotional posts.

\section{Conclusion}

Louis Althusser's argument on unions as Ideological State Apparatuses within a Repressive State Apparatus was used to highlight the abuse of the redeployment process to preserve the hegemony of the ruling class. A critical analysis of the redeployment process through Althusser's lens was also highlighted to help the reader determine whether there is congruency between policy formulation and policy implementation. While determining the outcome of the process, the reader was left to ponder the significance of the state in allowing unions to manipulate the masses through the process of interpellation. This article has used Althusser's theories to explain how the transactional leadership style is applied as an instrument of preserving the hegemony of the ruling class.

The necessity for raising the consciousness of people about the propensity of union infiltration in policy implementation regarding redeployment is a prerequisite for true freedom within the South African education system. The argument was further raised that the South African Democratic Teachers' Union through its association with the government fits the profile of a political Ideological State Apparatus. Findings of the research also show that the same union has been immensely influential in fortifying the emergence of the current ruling class. SADTU, therefore, in my view, continues to make a major contribution to the ideological role of the State as it "normalises" an immensely hierarchical society. Although Althusser's theories were born lout of an attempt to defend what some view as communist orthodoxy, I find Althusser's work critical, relevant and accurate in critiquing the redeployment process as means to an end to preserve the emergence of the ruling class.While I recognise SADTU's contribution to education transformation, I 
have argued that this union, as a politicised subject and through transactional leadership, perpetuates the reproduction of the relations of production with reference to aspects of ideological and political practice.

\section{References}

Akita EM 2010. Hegemony, Patriarchy and Human Rights: The Representation of Ghanaian Women in Politics. Published Doctoral Thesis. College of Education of Ohio University.

Althusser, L. 1971. Ideology and Ideological State Apparatuses: Lenin and Philosophy, and Other Essays (pp.127-188). Trans. Ben Brewster. London: New Left Books.

Bass, B.M. 1985. Leadership and performance beyond expectations. New York: Free Press.

Bascia, N. 2000. The Other Side of the Equation: Professional Development and the Organizational Capacity of Trade Unions. Educational Policy. Vol. 14 No 3: 385-404.

Burns, J.M. 1978. Leadership. New York: Harper \& Row.

Burchell, G. 1993. Liberal Government Techniques of the Self. Economy and Society, 22(3): 267-282.

Chisholm, L., Souden, C., Vally, S., and Gilmour, D. 1999. Teachers and Structural Adjustment in South Africa. Educational Policy. 13 (3): Corwin Press.

City Press Official Website. 2011. From<http://www.citypress.co.za/politics/mantashe-defends-anc-cadre-deployment-20110914-2 (Retrieved April 17, 2012).

Diko, N N, Letseka M 2009. Policy appropriation in teacher retention and attrition: the case of North-West Province. Perspectives in Education. 228-236.

Gall, J.P., Gall, M.D., Borg, W.R. 1999. Applying Educational Research. Fourth Edition, www.angelfire,com/or3/tss4/ggb1.jpg , Longman, Inc. New York.

Govender L. 1996. When the chalks are down: A historical, political and social interpretation of teacher militancy in South Africa. Pretoria: HSRC Publishers.

Heckroodt, A.S. 2002. The Role of the Gauteng Education and Training Council in Education Policy Making. Unpublished D. Ed. - Thesis, Pretoria: UNISA.

Heystek, J. and Lethoko, M. 2001. The Contribution of Teacher Unions in the Restoration of Directorate Budgeting Professionalism and the Culture of Learning and Teaching. South African Journal of Education. 21(4): 222-228.

Kerchner, C.T. \& Mitchell, D.E. 1988. The changing idea of a teachers' union. London: The Falmer Press.

Letseka, M., Bantwini, B., and King-McKenzie, E. 2012. Public-Union Sector Politics and the Crisis of Education in South Africa. Creative Education, I3(7): 1197-1204

Moe, T. 2011. Special interest: Teachers Unions and America's Public Schools. Washington DC Brookings Press.

Pattillo, K.M.C. 2012. Quiet Corruption: Teachers' Unions and Leadership in South African Directorate Budgeting Township Schools. Thesis submitted to the Wesleyan University. Middletown, Connecticut.

Peterson, B. 2006. Rethinking Teacher Unions. www.rethinkingschools.org. Milwaukee.

Pitsoe, V. 2012. Teaching Human Rights Education: A Foucauldian Discourse. Journal of Sociology Social Anthropology, 3(2): 153-161.

Pitsoe, V. and Letseka, M. 2013. Foucault's Discourse and Power: Implications for Instructionist Classroom Management. Open Journal of Philosophy, 3(1): 23-28.

Poole, W. L. 1999. Teachers Union Involvement in Educational Policy Making: Issues Raised by an In-Depth Case. Journal of Educational Policy, 13: $698-725$.

Republic of South Africa. 1995. The Labour Relations Act 66 of 1995. Pretoria: Government Printer.

Republic of South Africa. 1996. South African Schools Act 84 of 1996. Pretoria: Government Printer.

Republic of South Africa. 1998. The Employment of Educators Act 76 of 1998. Pretoria: Government Printer.

Republic of South Africa. 2005. Collective Agreement 2 of 2005. Pretoria: Government Printer.

Republic of South Africa. 2006. Circular 42 of 2006. Pretoria: Government Printer.

Republic of South Africa. 2006. Circular 43 of 2006. Pretoria: Government Printer.

Republic of South Africa. 2007. Circular 47 of 2007. Pretoria: Government Printer.

Sayed, Y. 2002. Educational Policy in South Africa: From Opposition to Governing and Implementation. International Journal of Educational Development. 22: 29-33.

Soudien, C. 2001. Teacher Responses to Rationalisation: Transformation and Adaptation in the Western Cape, South Africa. International Journal of Educational Development , 21: 33-43.

Taylor, N. 2008. "What's wrong with South African schools?" A Five Year Plan for South African Schooling. A Report Commissioned by the National Planning Commission. JET Education Services. Pretoria: Government Press.

The Economist. 2011. Briefing: Public-sector workers. The Economist: January 8-14.

Thembela, A.J. and Walters, R.A. (1984). Teaching Science 3. Cape Town: Maskew Miller Longman.

Van Onsellen, G. 2012. South African Political Dictionary: Cadre employment and cadre deployment at www.inside-politics.org (retrieved November 30, 2012).

Zengele, V.T. 2009. The Involvement of Teacher Unions in the Implementation of The Employment of Educators' Act 76 of 1998. D.Ed. Thesis (Published), Pretoria: University of South Africa.

Zengele, V.T. and Pitsoe, V.J. 2014. Louis Althusser on Politics and Processes of Filling Promotional Posts. Mediterranean Journal of Social Sciences. 5 (2): 333-340. 